\title{
TEACHERS' OPINIONS ON THE COMPETENCY OF PRIMARY SCHOOL ADMINISTRATORS IN KOSOVO
}

\section{Dr.sc. Nuri BRINA (iD $1 *$}

\author{
Assoc. Prof. Dr. Turan Akman ERKILIÇ (iD ${ }^{2}$ \\ 1 Prizren Ukshin Hoti University, Faculty of Education, nuri.brina@uni-prizren.com *Correspondent Author. \\ 2 Anadolu University, Faculty of Education, terkilic@anadolu.edu.tr
}

\author{
Article history: \\ Submission 01 August 2021 \\ Revision 08 November 2021 \\ Accepted 19 December 2021 \\ Available online 31 December 2021
}

\section{Keywords:}

Kosovo,

School Administrators,

Competence.

DOI:

https://doi.org/10.32936/pssj.v5i3.277

\begin{abstract}
A b st r a c t
In this study, it is aimed to determine the teachers' opinions on the school administrators competency in Kosovo, who work at primary schools. The data of the study were collected in the 2020-2021 academic year by using the School Administrators Competencies Inventory (SACI). In the analysis of the data, findings were obtained by using statistical analyses such as Correlation, Ttest and MANOVA. Based on the findings, it was found that the school administrators' competencies inventory is adequate in all dimensions. No significant difference was found based on the variables of the teachers' opinions, gender and educational level. A significant difference was found in the dimensions of preparing a convenient school building and environment and professional service as a result of the ethnic analysis. A significant difference was found in the dimension of the curriculum development under the views on the school administrators' competency based on age. Based on the results, it is recommended that school administrators can be encouraged to engage in personal and administrative activities and provide more opportunities, with a central systemic support, in order to have more positive effects on their competencies.
\end{abstract}

\section{Introduction}

The only way to reach beyond the age is through breakthroughs in education. Researching the competencies of school administrators, which is accepted by everyone to have an important place in the education system, is very necessary at the beginning of the twenty first century, especially in this age of change and information. The information age has emerged throughout the world as a result of the developing technology and information which has been produced in the twenty-first century (Aydın, 2000). Importance of management has increased in the information age due to the change in the lifestyles of individuals, technological developments, renewed business sectors and rapid changes in occupational characteristics. In this age, people have started to satisfy their needs through organizations. It is the managers who manage and organize those organizations well in order to satisfy the needs accurately and successfully.

In the information age, it has become a must to create environments which can meet different needs in educational organizations due to the complex and versatile nature of people, rapid changes in education and new approaches (Kurhan, 2009, p. 1). It should be perceived as a very important responsibility for the future to raise qualified people who will lead this rapid change, particularly for educational institutions (Demir, 2009). It is unimaginable that schools, which are information producing institutions, and the administrators who manage them, fall behind these processes (Aydın, 2000). However, the qualifications and the behaviors which managers in general and school administrators in particular, should have and exhibit have differentiated (Çetin, 2008). At this point, the school administrators' competencies gain importance (Baltacı, 2017). Although certain theoretical and applied researches have been performed on the determination of the competencies of school administrators in some European countries and Turkey, these competencies remained only theoretical and could not be translated into practice, since school administrating was not professionalized (Ağaoğlu, Altınkurt, Yılmaz, \& Karaköse, 2012). Nevertheless, school administrators need to have certain competencies in order to manage their schools effectively and efficiently. After all, there is a need for qualified employees who 
do their job well and who are competent in their field, as well as quality managers who will organize and direct them (Tuzcuoğlu, 2009).

\subsection{Problem}

It has been concluded that the most important of the interorganizational factors is the human factor as a result of the studies which were conducted in the social development process. As Özdemir (1988) stated, the fundamental element which guides education is human being. If the employees in this field cannot be trained and evaluated effectively enough, the problems of the education system continue exponentially. In line with this, the socio-economic, political, educational and cultural development of Kosovo, which is a 13-year-old state, depends on the condition of training human capital. This is possible with qualified education in the first place. It has been accepted by all the world that education is the most important element for the development of communities and for them to continue their lives in peace and prosperity (Barut, 2007). As a matter of fact, as Çelik (1990) stated, education lies behind the social, economic and political problems in many countries and it is considered to be locomotive power. The effective use of material and human capital resources allocated to education necessitated the organization of an adequate staff of school administrators who are trained in the field of educational administration (Çelik, 1990). In countries where trained human capital and financial resources are considered scarce, it can be suggested that school administrators' competencies are of greater importance (Kayıkçı, 2001). Therefore, it is observed that it is necessary for school administrators to have certain knowledge, abilities, conditions and behaviors.

One of the problem dimensions of the school administrators in Kosovo is that enough research on this subject has not been performed and it can be claimed that the researches merely consider the theoretical dimension. It can also be argued that the evaluation and development of effective school administrator's qualifications in Kosovo will contribute positively to the education service provided in schools.

The main subject of this study is the school administrators' competencies. In the context of Kosovo, a comprehensive study has been conducted to evaluate the existing practices in the education system and the information obtained through quantitative means in the dimension of school administrators' competence. Studies on this subject in the world and in Turkey exist, but as a result of the literature review, it makes this study much more valuable by constituting the main reason for making the study in Kosovo, which aims development to observe the limited number of such studies in the context of Kosovo, the inadequacy of the literature on the school administrators' competencies, the lack of awareness and qualifications, and the lack of awareness of such competencies in Kosovo.

\subsection{Purpose}

In this study, it is aimed to determine the teachers' opinions about the school administrators' competency in Kosovo based on the opinions of primary school teachers. In line with this general purpose, answers to the following questions are sought:

1. What are the teachers' views on the competencies of primary school administrators (principals and deputy principals) in Kosovo?

2. How do the teachers' opinions on the school administrators' competencies in Kosovo vary based on:

a) Gender,

b) Age,

c) Education level,

d) Ethnicity?

\subsection{The Concept of Competency}

Competency can be described as "having a certain level of knowledge and ability to perform a behavior (Kaya 1993; Başaran, 2006), a whole consisting of certain personal characteristics (Bursalıoglu, 1981) and abilities which enable a person to survive in the social system" (Balc1, 2003). The perception of competency which an individual has can make it possible to do their work more easily, both in daily and working life (Baltac1, 2017). Başaran (2006) argues that the reliability in employing competency comes from the fact that the knowledge and skills on which it is based are of scientific origin.

Manager competencies, on the other hand, can be considered as a performance criterion consisting of knowledge, skills, attitudes, values and behaviors which are expected from managers in order for the organization to achieve its goals. However, these criteria differ according to the management perspective of the manager, and these competencies also change in parallel with the changes in management science (Gökçe, 2008). Furthermore, managerial competencies imply what is expected from managers in providing organizational effectiveness in the most general sense. These are characteristics which need to be addressed in a wide variety, from technology use to communication and leadership competencies. In this sense, it is very difficult to connect the theoretical background of managerial competencies to a standard theory (Ağaoğlu, Altunkurt, Yılmaz, \& Karaköse, 2012).

It is of great importance to know the areas of competencies in administration, especially in school administration. These 
competencies are determined legally by the relevant ministries, and different criteria have been put forward by the academic circles (Gülşen \& Gökyer, 2012). Katz (citing from 1956, Bursalığlu, 1981), who has an important role in the literature, determined the competencies which school administrators should have as technical, human and organizational (conceptual) based on the results of his research. Suggesting a similar explanation, Şişman (2013) argues that school administrators should have some skills and competencies in human, technical and conceptual aspects. This classification is also widely used in educational administration studies. This is because these competencies can be determined easily and reliably in terms of the knowledge and skills which they cover (Bursalığlu, 1981).

Based on the results of his applied research, Aydın (2014) collects the competencies of the school administrator under the headings of working effectively with people, an effective business management, preparing a convenient school building and its environment, developing a training program, and serving the profession. Again, it can be claimed that Aydin (2014) focuses on the human, organizational and technical competencies of school administrators. In the studies which were conducted by Uslu, (2013) and Can, (2014), Açıkalın (1998); Basar, (2000); Toremen ve Kolay (2003); Munis, (2006); Kombiçak, (2008); Lunenburg, (2010); it is also observed that they classify the competencies of school administrators based on similar points.

Based on the descriptions in the literature, human competencies, organizational competencies and technical competencies can be explained as follows; Human competencies are the ability of school administrators to work with people (Başar, 2000). These are the competencies which the administrator should have in human affairs such as being a good team leader and establishing and developing good workplace relations (Şişman, 2012). Organizational competencies are the ability to manage and consider the organization from an institutional and conceptual perspective (Kayıkçı, 2001). Technical competencies, on the other hand, include the technical knowledge and skills which school administrators need to know in the field of work related to the tools and equipment which are used in business life (Açıkgöz, 1994; Eren, 2012). School administrators can gain some of them through the education they receive, and some of them through experience while working (Şişman, 2012). A school administrator with mentioned scope of competency can manage the school more effectively (Balyer, 2016). As a result, school administrators can be more successful in their organizations if they have effective competencies and skills in these areas.

\section{Research Method}

The research dimension of the study has been designed in the descriptive survey model. The survey model is a research approach which aims to describe a past or present situation as it is or was (Büyüköztürk, Çakmak, Akgün, Karadeniz, \& Demirel, 2010). The descriptive survey model is a research model which tries to describe and examine events, entities, groups, and features in the preexisting condition (Kaptan, 1998). The main purpose of this type of research is to describe and explain the considered situation in detail (Çepni, 2007).

\subsection{The Universe which was Created for data} Collection and Sample

The general universe of the research consists of 23,234 (10,069 female and 13,165 male) teachers working at primary and secondary level (educational level) in Kosovo in the 2020-2021 academic year (MASHT, 2020). It was decided to take sample in the study due to the fact that the universe becomes abstract as it increases in number and it becomes difficult to access the members (Karasar, 2008). The population of 6,336 teachers was calculated considering the confidence interval of $95 \%$ and the margin of error of $5 \%$, and minimum sample number to represent the population was 362 in order to be sure in the determination of the sample which is sufficient to represent the universe in the study.

As Yıldırım and Şimşek (2016) stated, schools in the city and district centers were preferred by using the easily accessible sampling method in the study, since the schools which are close and easy to reach should be selected. In this method, the researcher chooses a situation which is close and easy to access (Patton, 2005; Yıldırım \& Şimşek, 2016).

The power of representation of the universe in sample selection is extremely important in terms of ensuring the validity and reliability of the study. For this reason, the data on the number of teachers in the sample of the study are shown in Table 1 below (MASHT, 2020) 
Table 1. The distribution of ethnicity of the teachers who constitute the research universe and sample in the provinces and districts):

\begin{tabular}{|c|c|c|c|c|c|}
\hline \multicolumn{6}{|c|}{ Number of the Teachers in the Research Universe } \\
\hline $\begin{array}{l}\text { Provinces and } \\
\text { Districts }\end{array}$ & Albanian & Turkish & Bosnian & Other & TOTAL \\
\hline Prishtine & 2,632 & 21 & 12 & / & 2,665 \\
\hline Prizren & 1,837 & 107 & 261 & 8 & 2,213 \\
\hline Gilan & 1,375 & 24 & / & 2 & 1,401 \\
\hline Mamusa & 16 & 41 & / & / & 57 \\
\hline TOTAL & 5,860 & 193 & 273 & 10 & 6,336 \\
\hline \multicolumn{6}{|c|}{ Number of the Teachers in the Sample } \\
\hline $\begin{array}{l}\text { Provinces and } \\
\text { Districts }\end{array}$ & Albanian & Turkish & Bosnian & Other & TOTAL \\
\hline Prishtine & 42 & 16 & 2 & I & 60 \\
\hline Prizren & 199 & 111 & 139 & I & 449 \\
\hline Gilan & 35 & 14 & I & I & 49 \\
\hline Mamusa & 9 & 32 & 1 & I & 42 \\
\hline TOTAL & 285 & 173 & 142 & I & 600 \\
\hline
\end{tabular}

As can be seen in Table 1, 6,336 Albanian, Turkish and Bosnian teachers are in the study population of the research. 5,860 of the teachers are Albanian, 193 are Turkish, 273 are Bosnian and 10 are from other ethnic identities.

It is also can be seen that, the total number of Albanian teachers in the sample is $285(47.50 \%) .4 .86 \%$ of the Albanian teachers in the study universe were taken into the sample. 173 of the teachers are Turkish (28.83\%). 89.63 of the teachers in the study universe were taken into the sample. The number of Bosnian teachers is $142(23,66 \%) .52 .01 \%$ of Bosnian teachers in the study universe were taken into the sample. The representation ratio of the number of teachers (600) who are included in the sample to the study population is $9.46 \%$. Based on this information, the researcher comes to the conclusion that the level of representation of the population of the sample which are reached is quite sufficient.

750 forms were distributed to the study universe of the study, 24 of the 624 returned forms were not included in the study as they were incomplete, and a total of 600 people were included in the sample. The personal details of the teachers who participated in the quantitative research is presented in Table 2 .

Table 2. Personal details of the teachers who participated in the study

\begin{tabular}{|c|c|c|c|}
\hline Ethnic Origin & Frequency & Percentage & Total percentage \\
\hline Albanian & 285 & 47.500 & 47.500 \\
\hline Turkish & 172 & 28.667 & 76.167 \\
\hline Bosnian & 143 & 23.833 & 100.000 \\
\hline Total & 600 & 100.000 & \\
\hline \multicolumn{4}{|l|}{ Gender } \\
\hline Female & 373 & 62.167 & 62.167 \\
\hline Male & 227 & 37.833 & 100.000 \\
\hline Total & 600 & 100.000 & \\
\hline \multicolumn{4}{|l|}{ Age } \\
\hline $22-25$ & 38 & 6.333 & 6.333 \\
\hline $26-30$ & 91 & 15.167 & 21.500 \\
\hline $31-35$ & 110 & 18.333 & 39.833 \\
\hline $36-45$ & 184 & 30.667 & 70.500 \\
\hline 46 and older & 177 & 29.500 & 100.000 \\
\hline Total & 600 & 100.000 & \\
\hline
\end{tabular}


Educational level

\begin{tabular}{|c|c|c|c|}
\hline Higher Pedagogical Education School (2 years) & 44 & 7.333 & 7.333 \\
\hline Bachelor Completion (YPO+2) & 342 & 57.000 & 74.833 \\
\hline Undergraduate Education & 147 & 24.500 & 99.333 \\
\hline Postgraduate & 63 & 10.500 & 17.833 \\
\hline Doctorate & 4 & 0.667 & 100.000 \\
\hline Total & 600 & 100.000 & \\
\hline \multicolumn{4}{|l|}{ Branch } \\
\hline Classroom Teacher & 238 & 39.667 & 39.667 \\
\hline Branch Teacher & 288 & 48.000 & 87.667 \\
\hline Preschool Teacher & 59 & 9.833 & 97.500 \\
\hline Other & 14 & 2.333 & 99.833 \\
\hline Unspecified & 1 & 0.167 & 100.000 \\
\hline Total & 600 & 100.000 & \\
\hline \multicolumn{4}{|l|}{ Professional seniority } \\
\hline 5 years and less & 137 & 22.833 & 22.833 \\
\hline $6-10$ years & 134 & 22.333 & 45.167 \\
\hline $11-15$ years & 109 & 18.167 & 63.333 \\
\hline $16-20$ years & 67 & 11.167 & 74.500 \\
\hline 21 years and more & 153 & 25.500 & 100.000 \\
\hline Total & 600 & 100.000 & \\
\hline \multicolumn{4}{|l|}{ Place of duty } \\
\hline Prizren & 449 & 74.833 & 74.833 \\
\hline Prishtine & 60 & 10.000 & 84.833 \\
\hline Gilan & 49 & 8.167 & 93.000 \\
\hline Mamusa & 42 & 7.000 & 100.000 \\
\hline Total & 600 & 100.000 & \\
\hline
\end{tabular}

Considering Table 2, which presents the number of teachers included in the sample group and from whom data was obtained, it is observed that total 600 teachers have participated in the research. 285, 172 and 143 of the participants are Albanians, Turks and Bosnians, respectively. Based on the gender variable, it consists of 373 female and 227 male participants, and it is seen that $38,91,110,184$ and 177 of the participants belong to age ranges of $22-25$ years, $26-30$ years, $31-35$ years, $36-45$ years, 46 years old and over, respectively. Examining the educational status of the teachers, 44 of them graduated from the Higher Pedagogical School (2 years), 342 from the Bachelor's Degree (YPO+2), 147 from the Undergraduate Education, 63 from the Master's and 4 from the Doctorate. Based on the branch variable, it is observed that the 238, 288, 59 and 14 of the teachers are Class Teacher, Branch Teacher, Preschool Teacher, Other and Not Specified, respectively. Considering professional seniority, 137, 134, 109, 67 and 153 of the teachers have professional experience of 5 years and below, 6-10 years, 11-15 years, 16-20 years, 21 years and above, respectively. It is seen that 449, 60, 49 and 49 of the teachers work in Prizren, Pristina, Gilan and Mamusa, respectively.

\section{Results}

As a result, it can be stated that the teachers in the sample are Albanians in accordance with the demographic structure of Kosovo, most of the participants are female, between the ages of $36-45$, their education level consists of undergraduate completion and branch teachers.

\subsection{Findings on the Analysis of the School}

\section{Administrators Competency Inventory}

\section{Dimensions by Gender}

In the study, it is aimed to examine the dimensions of the inventory of school administrators' competencies based on gender which are communication with people and working effectively, preparing a convenient school building and environment, effective organizational management, professional service and curriculum development. In line with this purpose, independent groups T-test analysis was used to determine the variation of teachers based on gender. Means and standard deviations of scores obtained in the analysis and test results are presented in Table 3 (variances are equal). 
Table 3. T-test results of the school administrators' competency inventory dimensions by gender

\begin{tabular}{|c|c|c|c|c|c|c|c|c|c|}
\hline Variables & Group & $\mathbf{N}$ & Mean & $\mathbf{S} \mathbf{s}$ & S h & $\mathbf{t}$ & Sd. & $\mathbf{p}$ & Cohen d \\
\hline \multirow{2}{*}{$\begin{array}{l}\text { Communication With People } \\
\text { And Working Effectively }\end{array}$} & Female & 369 & 53.664 & 8.374 & 0.436 & 1.425 & 460.300 & 0.155 & 0.121 \\
\hline & Male & 226 & 52.628 & 8.738 & 0.581 & & & & \\
\hline \multirow{2}{*}{$\begin{array}{l}\text { Preparing a Convenient } \\
\text { School Building and } \\
\text { Environment }\end{array}$} & Female & 369 & 21.423 & 2.950 & 0.154 & 4.078 & 386.385 & .001 & 0.355 \\
\hline & Male & 226 & 20.208 & 3.837 & 0.255 & & & & \\
\hline \multirow{3}{*}{ Professional Service } & Female & 369 & 46.136 & 6.785 & 0.353 & 3.799 & 414.513 & .001 & 0.327 \\
\hline & & & & & & & & & \\
\hline & Male & 226 & 43.695 & 8.069 & 0.537 & & & & \\
\hline \multirow{2}{*}{$\begin{array}{l}\text { Effective Organizational } \\
\text { Management }\end{array}$} & Female & 369 & 33.154 & 4.864 & 0.253 & 2.506 & 433.906 & 0.013 & 0.215 \\
\hline & Male & 226 & 32.044 & 5.464 & 0.363 & & & & \\
\hline \multirow{2}{*}{ Curriculum Development } & Female & 369 & 38.005 & 5.430 & 0.283 & 2.408 & 441.666 & 0.016 & 0.206 \\
\hline & Male & 226 & 36.832 & 5.967 & 0.397 & & & & \\
\hline
\end{tabular}

As can see in Table 3, communicating with people and working effectively which is one of the dimensions of the school administrators' competencies inventory do not vary by gender. On the other hand, women's averages are statistically significantly higher than those of men in terms of preparing a convenient school building and environment, effective organizational management, professional service and curriculum development.

\subsection{Findings on the Analysis of the School}

\section{Administrators Competency Inventory \\ Dimensions by Ethnic Origin}

In the study, it is aimed to examine the dimensions of the inventory of school administrators' competencies based on ethnic origin which are communication with people and working effectively, preparing a convenient school building and environment, effective organizational management, professional service and curriculum development. In this context, multiple analysis of variance (MANOVA) was used to determine the variation of teachers according to ethnicity in the context of these variables. The Manova assumptions were maintained and the Wilks' Lambda test was used as the covariates were not equal (box test $\mathrm{p}=.001$ ). The correlations between the dependent variables of the study were examined and it was determined that there was no multi-collinearity. In the study, Bonferoni was applied in univariate analyzes to prevent type 1 error (Huck, 2012; Pallant, 2007). Accordingly, the $\mathrm{p}$ value of 0.005 was divided by the dependent variable of 5 , and the new $\mathrm{p}$ value was determined as 0.01 . According to the obtained results, it was determined that the multivariate test was significant. Wilk $\Lambda=$. $0.021, \mathrm{~F}(5,590)=5484.70, \mathrm{p}<0.001$, multivariate $\mathrm{\eta p} 2=.0 .98$. The results of the univariate tests are presented in Table 4.

Table 4. Variance analysis results of the school administrators' competency inventory dimensions by ethnic origin

\begin{tabular}{|c|c|c|c|c|c|c|c|}
\hline $\begin{array}{l}\text { Source of } \\
\text { Variance }\end{array}$ & $\begin{array}{l}\text { Dependent } \\
\text { Variable }\end{array}$ & KT & Sd & KO & $\mathbf{F}$ & $\mathbf{p}$ & $\eta_{p}^{2}$ \\
\hline \multirow{9}{*}{ Constant } & Communication & 1542294,256 & 1 & 1542294,256 & 21269,025 & 0,000 & 0,973 \\
\hline & With People And & & & & & & \\
\hline & Working & & & & & & \\
\hline & Effectively & & & & & & \\
\hline & Preparing a & & & & & & \\
\hline & Convenient School & 238057,088 & 1 & 238057,088 & 21275,106 & 0,000 & 0,973 \\
\hline & Building and & & & & & & \\
\hline & Environment & & & & & & \\
\hline & Professional Service & 1106828,417 & 1 & 1106828,417 & 20571,141 & 0,000 & 0,972 \\
\hline
\end{tabular}




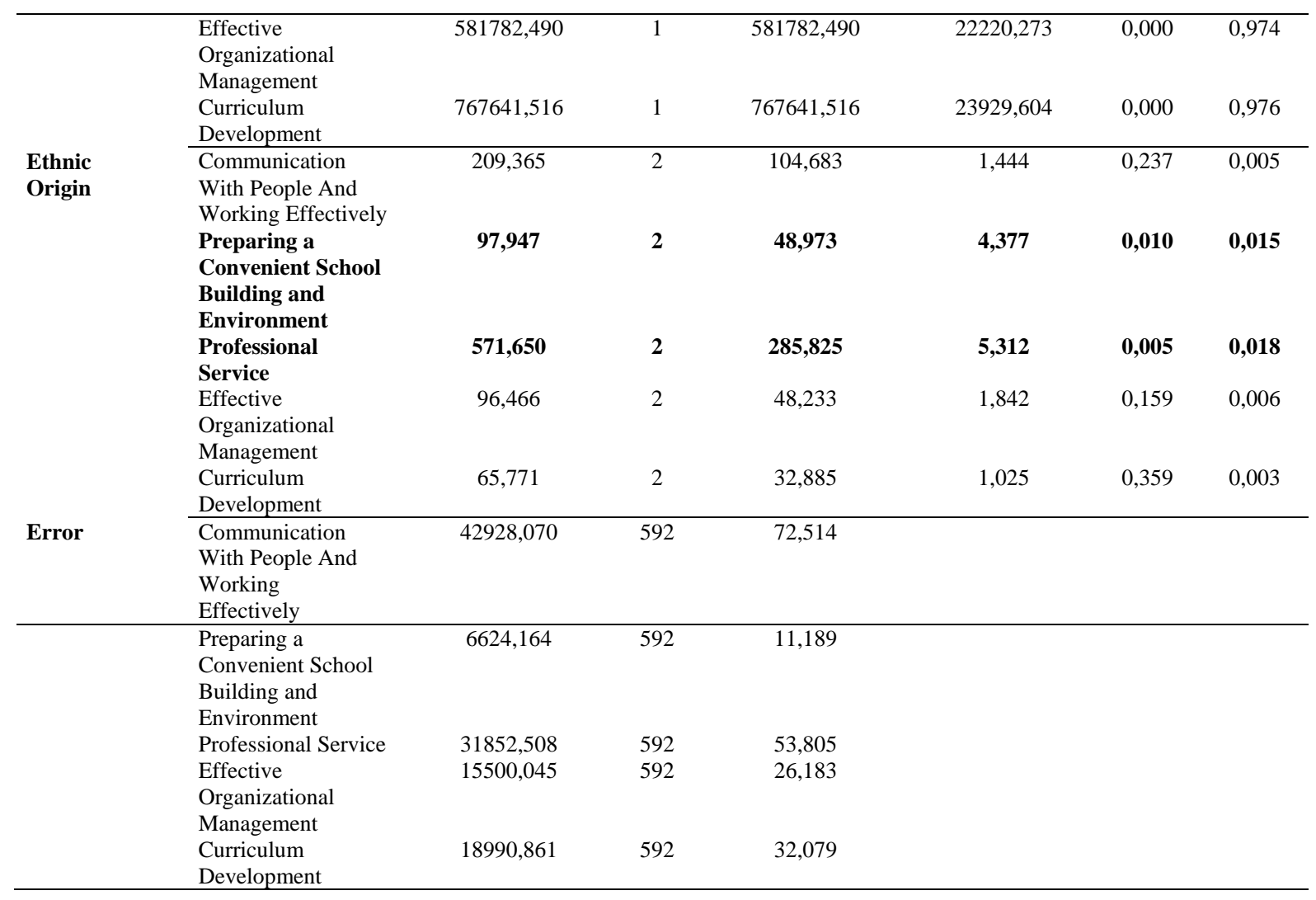

As indicated in Table 4, a significant difference is found in preparing a convenient school building and environment $\mathrm{F}$ (2, $592)=4.377, \mathrm{p}=.01 ; \eta \mathrm{p} 2=0.015$ and in professional service $\mathrm{F}$ $(2,592)=5.312, \mathrm{p}=.005 ; \eta \mathrm{p} 2=0.018$. For other variables, no statistical difference is detected. Tukey test was used to determine the resulting difference, since the variances were equal, and the results are presented in Table 5.

Table 5. Tukey test results related to the ethnic origin variable of the school administrators' competency inventory dimensions

\begin{tabular}{|c|c|c|c|c|c|}
\hline Dependent Variable & Ethnic origin & & Mean Difference & sh & $\mathbf{p}$ \\
\hline \multirow{6}{*}{$\begin{array}{l}\text { Preparing a convenient school } \\
\text { building and Enviroment }\end{array}$} & Albanian & Turkish & 0,0838 & 0,32459 & 0,964 \\
\hline & \multirow{3}{*}{ Turkish } & Bosniak & ,9796" & 0,34400 & 0,013 \\
\hline & & Albanian & $-0,0838$ & 0,32459 & 0,964 \\
\hline & & Bosniak & ,8959* & 0,38029 & 0,049 \\
\hline & \multirow[t]{2}{*}{ Bosniak } & Albanian &,$- 9796^{*}$ & 0,34400 & $\mathbf{0 , 0 1 3}$ \\
\hline & & Turkish &,$- 8959^{*}$ & 0,38029 & 0,049 \\
\hline \multirow{6}{*}{ Professional Service } & \multirow[t]{2}{*}{ Albanian } & Turkish & 0,0162 & 0,71177 & 1,000 \\
\hline & & Bosniak & $2,3055^{*}$ & 0,75434 & 0,007 \\
\hline & \multirow[t]{2}{*}{ Turkish } & Albanian & $-0,0162$ & 0,71177 & 1,000 \\
\hline & & Bosniak & $2,2893^{*}$ & 0,83391 & $\mathbf{0 , 0 1 7}$ \\
\hline & \multirow[t]{2}{*}{ Bosniak } & Albanian & $-2,3055^{*}$ & 0,75434 & 0,007 \\
\hline & & Turkish & $-2,2893^{*}$ & 0,83391 & $\mathbf{0 , 0 1 7}$ \\
\hline
\end{tabular}

As can be seen in Table 5, the scores of Albanian and Turkish ethnic groups are statistically significantly higher than Bosniak participants in the dimension of preparing a convenient school building and its environment. Similarly, the scores of Albanian and Turkish ethnic groups are statistically significantly higher than Bosniak individuals in the dimension of professional service. 


\subsection{Findings on the Analysis of the School \\ Administrators' Competency Inventory \\ Dimensions by Age}

In the study, it is aimed to examine the dimensions of the school administrators' competencies inventory based on age which are communication with people and working effectively, preparing a convenient school building and environment, effective organizational management, professional service and curriculum development. In this framework, multiple analysis of variance (MANOVA) was used to determine the variation of teachers based on age in the context of these variables. Manova assumptions were maintained and covariates were found to be unequal (box test $\mathrm{p}=.001$ ). Wilks' Lambda test was used. The correlations between the dependent variables of the study were examined and it was determined that there was no multicollinearity. In the study, Bonferoni was applied in univariate analyzes to prevent type 1 error (Huck, 2012; Pallant, 2007). Accordingly, the $\mathrm{p}$ value of 0.005 was divided by the dependent variable of 5 , and the new $\mathrm{p}$ value was determined as 0.01 . Considering the obtained results, it is determined that the multivariate test is significant. Wilk $\Lambda=0.951, \mathrm{~F}(5.589)=1.491$, $\mathrm{p}<0.05$, multivariate $\eta \mathrm{p} 2=0.013$. The results of the univariate tests are given in Table 6.

Table 6. Analysis of variance results related to the age variable of the school administrators' competency inventory dimensions

\begin{tabular}{|c|c|c|c|c|c|c|c|}
\hline $\begin{array}{l}\text { Source of } \\
\text { Variance }\end{array}$ & Dependent Variable & KT & Sd & KO & $\mathbf{F}$ & $\mathbf{p}$ & $\eta_{p}^{2}$ \\
\hline \multirow[t]{5}{*}{ Constant } & $\begin{array}{l}\text { Communication With People And } \\
\text { Working Effectively }\end{array}$ & 1240148,3 & 1 & 1240148,37 & 17201,30 & 0,000 & 0,967 \\
\hline & $\begin{array}{l}\text { Preparing a Convenient School } \\
\text { Building and Environment }\end{array}$ & 191035,35 & 1 & 191035,359 & 17027,11 & 0,000 & 0,967 \\
\hline & Professional Service & 888283,72 & 1 & 888283,728 & 16520,54 & 0,000 & 0,966 \\
\hline & $\begin{array}{l}\text { Effective Organizational } \\
\text { Management }\end{array}$ & 464812,07 & 1 & 464812,070 & 17810,42 & 0,000 & 0,968 \\
\hline & Curriculum Development & 617546,94 & 1 & 617546,943 & 19573,94 & 0,000 & 0,971 \\
\hline \multirow[t]{5}{*}{ Age } & $\begin{array}{l}\text { Communication With People And } \\
\text { Working Effectively }\end{array}$ & 600,684 & 4 & 150,171 & 2,083 & 0,082 & 0,014 \\
\hline & $\begin{array}{l}\text { Preparing a Convenient School } \\
\text { Building and Environment }\end{array}$ & 102,619 & 4 & 25,655 & 2,287 & 0,059 & 0,015 \\
\hline & Professional Service & 700,784 & 4 & 175,196 & 3,258 & 0,012 & 0,022 \\
\hline & $\begin{array}{l}\text { Effective Organizational } \\
\text { Management }\end{array}$ & 198,836 & 4 & 49,709 & 1,905 & 0,108 & 0,013 \\
\hline & Curriculum Development & 442,464 & 4 & 110,616 & 3,506 & 0,008 & $\mathbf{0 , 0 2 3}$ \\
\hline \multirow[t]{5}{*}{ Error } & $\begin{array}{l}\text { Communication With People And } \\
\text { Working Effectively }\end{array}$ & 42536,751 & 590 & 72,096 & & & \\
\hline & $\begin{array}{l}\text { Preparing a Convenient School } \\
\text { Building and Environment }\end{array}$ & 6619,492 & 590 & 11,219 & & & \\
\hline & Professional Service & 31723,374 & 590 & 53,768 & & & \\
\hline & $\begin{array}{l}\text { Effective Organizational } \\
\text { Management }\end{array}$ & 15397,675 & 590 & 26,098 & & & \\
\hline & Curriculum Development & 18614,168 & 590 & 31,549 & & & \\
\hline
\end{tabular}

As can be seen in Table 6, a significant difference is found in $\mathrm{F}$ $(4,590)=3,506, \mathrm{p}=0.008, \mathrm{np} 2=0.023$ development of curriculum dimension. For other variables, no statistical difference was detected. Tukey test was used to determine the difference since the variances were equal and the results are presented in Table 7.

Table 7. Tukey test results related to the age variable of the school administrators' competency inventory dimensions

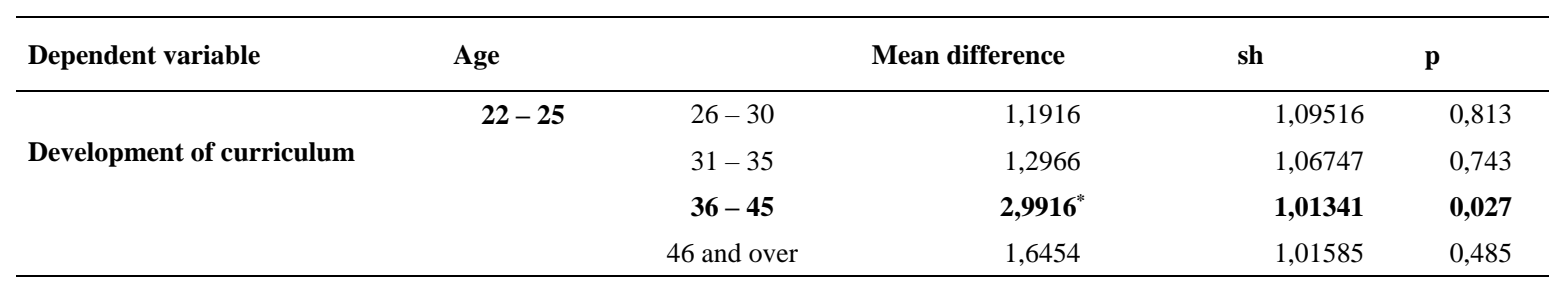




\begin{tabular}{ccccc}
\hline $26-30$ & $22-25$ & $-1,1916$ & 1,09516 & 0,813 \\
& $31-35$ & 0,1050 & 0,79593 & 1,000 \\
& $36-45$ & 1,8001 & 0,72181 & 0,093 \\
& 46 and over & 0,4539 & 0,72523 & 0,971 \\
\hline $31-35$ & $22-25$ & $-1,2966$ & 1,06747 & 0,743 \\
& $26-30$ & $-0,1050$ & 0,79593 & 1,000 \\
& $36-45$ & 1,6951 & 0,67906 & 0,093 \\
& 46 and over & 0,3489 & 0,68269 & 0,986 \\
\hline
\end{tabular}

As can be seen in Table 7, the scores of those in the 22-25 age are statistically significantly higher than those in the 36-45 age range in the dimension of developing curriculum.

\subsection{Findings on the Analysis of the School Administrators' Competency Inventory Dimensions by Educational Level}

In the study, it is aimed to examine the dimensions of the school administrators' competencies inventory based on educational level which are communication with people and working effectively, preparing a convenient school building and environment, effective organizational management, professional service and curriculum development. In this framework, multiple analysis of variance (MANOVA) was used to determine the variation of teachers based on educational level in the context of these variables. Manova assumptions were maintained and covariates were found to be unequal (box test $\mathrm{p}=.001$ ). Wilks' Lambda test was used. The correlations between the dependent variables of the study were examined and it was determined that there was no multi-collinearity. In the study, Bonferoni was applied in univariate analyzes to prevent type 1 error (Huck, 2012; Pallant, 2007). Accordingly, the p value of 0.005 was divided by the dependent variable of 5 , and the new $\mathrm{p}$ value was determined as 0.01. Considering the obtained results, it is determined that the multivariate test is significant. Wilk $\Lambda=$ $0.973, \mathrm{~F}(5.589)=1.086, \mathrm{p}>0.05$, multivariate $\eta \mathrm{p} 2=0.009$. As can be seen in Table 8 , the results of the univariate tests did not change based on the education level.

Table 8. Univariate test results of the school administrators' competency inventory dimensions by educational level

\begin{tabular}{|c|c|c|c|c|c|c|c|}
\hline $\begin{array}{l}\text { Source of } \\
\text { Variance }\end{array}$ & Dependent Variable & KT & Sd & KO & $\mathbf{F}$ & $\mathbf{p}$ & $\eta_{p}^{2}$ \\
\hline \multirow[t]{5}{*}{ Constant } & $\begin{array}{l}\text { Communication With People And } \\
\text { Working Effectively }\end{array}$ & 941146,126 & 1 & 941146,126 & 12978,181 & 0,000 & 0,956 \\
\hline & $\begin{array}{l}\text { Preparing a Convenient School Building } \\
\text { and Environment }\end{array}$ & 145643,869 & 1 & 145643,869 & 12824,849 & 0,000 & 0,956 \\
\hline & Professional Service & 683255,769 & 1 & 683255,769 & 12504,320 & 0,000 & 0,955 \\
\hline & Effective Organizational Management & 354724,143 & 1 & 354724,143 & 13500,465 & 0,000 & 0,958 \\
\hline & Curriculum Development & 463258,534 & 1 & 463258,534 & 14472,960 & 0,000 & 0,961 \\
\hline \multirow[t]{5}{*}{$\begin{array}{l}\text { Educational } \\
\text { level }\end{array}$} & $\begin{array}{l}\text { Communication With People And } \\
\text { Working Effectively }\end{array}$ & 279,551 & 3 & 93,184 & 1,285 & 0,279 & 0,006 \\
\hline & $\begin{array}{l}\text { Preparing a Convenient School Building } \\
\text { and Environment }\end{array}$ & 10,490 & 3 & 3,497 & 0,308 & 0,820 & 0,002 \\
\hline & Professional Service & 130,986 & 3 & 43,662 & 0,799 & 0,495 & 0,004 \\
\hline & Effective Organizational Management & 68,011 & 3 & 22,670 & 0,863 & 0,460 & 0,004 \\
\hline & Curriculum Development & 139,576 & 3 & 46,525 & 1,454 & 0,226 & 0,007 \\
\hline Error & $\begin{array}{l}\text { Communication With People And } \\
\text { Working Effectively }\end{array}$ & 42857,884 & 591 & 72,518 & & & \\
\hline
\end{tabular}


Preparing a Convenient School Building and Environment

Professional Service

Effective Organizational Management
$6711,621 \quad 591 \quad 11,356$

$32293,172 \quad 591 \quad 54,642$

$15528,500 \quad 591 \quad 26,275$

$18917,056 \quad 591 \quad 32,009$

\section{Conclusions, Discussion and Suggestions}

T-test results of communicating with people and working effectively which is one of the dimensions of the school administrators' competencies inventory do not differ based on gender. Considering this result, it can be claimed that teachers' school administrators' competency inventory is not affected by the gender variable and gender difference is not an important factor in determining the school administrators' competencies. Thus, it can be suggested that the opinions of both male and female teachers are similar and they hold similar views. As a consequence, it indicates that both genders evaluate the school administrators' competencies in a similar way. Accordingly, school administrators' competencies in communicating and working effectively are considered sufficient by both male and female teachers. It can be claimed that there is a parallelism between this result and the results obtained from studies in the literature by Ağaoğlu et al., (2012); Asar (2014); Ozdere (2015); Tümkaya and Asar (2017); Gök (2017) and Yalçın (2019). According to Gök (2017), this is due to the similar administrative activities which are performed by school administrators. It can be explained as the existence of similar activities lead to the similar communication competency.

It can be concluded that the mean of women is statistically significantly higher than men in the dimensions of preparing a convenient school building and environment, an effective organizational management, professional service and development of curriculum, which are the other dimensions of the inventory. Female teachers are found to consider school administrators' competency adequate in these dimensions of the inventory. According to this result, female teachers have higher opinions about the other dimensions of the inventory apart from communicating with people and working effectively. In line with these results, the fact that school administrators are familiar with their behaviors as a role model by encountering them in the same cultural environment may be due to the fact that female teachers' professional roles are different and their professional satisfaction is higher. Yalçın (2019) has found that male administrators were more competent in the dimension of "curriculum development " in the comparison made by gender. Female teachers, on the other hand, find male administrators more competent in terms of "professional service ". The researcher states that this was due to the fact that male managers have more knowledge and experience. We can state that these results do not match the results of our study.

As a result of the ethnic origin analysis, a significant difference was found in the dimensions of preparing a convenient school building and environment and professional service. We can state that teachers and school administrators have positive opinions based on the dimensions of the school administrators' inventory, preparing a convenient school building and environment, and professional service. It can be said that teachers and school administrators are of the opinion that the achievements in these dimensions of competencies are sufficient. However, since Kosovo is a newly established state and has the aim of development, it is possible to say that it is necessary to concentrate more on these dimensions and to make school administrators more competent by making improvements and restructuring. Therefore, we can state that school administrators and related institutions should work on these dimensions.

Tukey test was conducted to determine how the school administrators' competencies vary based on the ethnic origin. As a result of this analysis, the scores of Albanian and Turkish ethnic groups are statistically significantly higher than Bosniak participants in terms of preparing a convenient school building and environment and professional service. Albanians and Turks consider these items more adequate than Bosnians. According to this result, we can state that Albanian and Turkish teachers internalize these dimensions of the inventory more than Bosnian teachers do and identify with them, and consider school administrators' competency gains adequate. This may be due to the fact that Albanians are familiar with domestic and international literature while Turks are also familiar with studies in Turkey. It can be claimed that Turks in Kosovo are more conscious, particularly, in terms of preparing a convenient school building and environment and professional service in order to preserve their ethnic and cultural existence, and it can be an important factor for their attitude. It can be argued that considering these dimensions is essential for a healthy and effective management and school administrators' competencies. No statistical difference was found in other dimensions. It can be stated that there are similarities in the teachers' opinions at this point, so they consider the school administrators' competencies adequate. This may be due to the fact that the multicultural 
structure of Kosovo has positively affected the opinions, and the social and cultural thought structures are similar to each other.

A significant difference was found in the opinions on the curriculum development dimension of the school administrators' competencies, in the analysis based on age. The reason for this may be due to the fact that school administrators have more control over the curriculum. Tukey test was used to determine the resulting difference, since the variances were equal. In the dimension of curriculum development, the, the scores of those between the ages of 22-25 are statistically significantly higher than those between the ages of 36-45. According to this, it can be said that the teachers who are in the 22-25 age range consider school administrators more competent in the curriculum development compared to the teachers who are in the 36-45 age range. It can be claimed that this result is similar to the result of the study by Tümkaya and Asar (2017) that the perceptions of managers regarding their competencies differ significantly based on age. However, in the study of Tümkaya and Asar (2017), it was determined that the difference in all dimensions of the inventory was caused by administrators who were 51 and over and the administrators from other age groups, and this difference was in favor of administrators who were 51 and over.

In our study, it can be argued that the significant difference in age may be due to the increase in the experience of the teachers as they age. Another reason for the difference in age groups may be due to the fact that a gap exists among the views although both young and old teachers work in the same environment and share knowledge. The reason for this can be explained by the fact that knowledge can be obtained relatively easily as a result of various activities (educational lessons, teaching practice, etc.) of the intensive curriculum which are conducted by the teachers throughout their educational life, and with the development of technology in today's information age. On the other hand, since the curriculums in Kosovo are usually assigned by the central organization, it can be thought that teachers want school administrators, especially school administrators, to take part in the curriculum development. As a result of the teachers' opinions, it is possible to interpret it as an opportunity for the development of the competencies of the school administrators by taking the dimension of the curriculum development into consideration. No statistical difference was found in other dimensions. This indicates that teachers have similar thoughts and expectations regarding the school administrators' competencies.

It is determined that the multivariate test is not significant based on the results obtained in the analysis for educational level. In line with these data which were obtained from the participants of the study, it can be claimed that the dimensions of the inventory do not have a statistically significant effect. This result can be interpreted as the fact that educational level of teachers has no effect in determining school administrators' competency.

Therefore, there is no significant difference in terms of stating the administrators' opinions about the level of their competencies. In the analyses which were formerly performed in the literature; Açıkalın (2000); Akcay (2000); Çetin (2001) and Doğan (2006) did not find a significant difference based on the variable of educational level. However, Tümkaya and Asar (2017) found a statistical difference in the perceptions of administrators' competencies in all dimensions except for "professional service" based on the educational level and revealed that the difference differed significantly in favor of administrators with graduate education. The findings of the study by Tümkaya and Asar (2017) regarding the level of education differ from the findings of this study. We can argue that this is due to the fact that the scope of the applied inventory is wide, different perspectives prevail in different geographies, and seniority increases with age.

\section{References}

1. Açıkalın, A. (1998). Toplumsal kurumsal ve teknik yönleriyle okul yöneticiliği. (4. Baskı). Ankara: Pegem Yayıncılık, ISBN: 9757251011

2. Açıkgöz, K. (1994). Eğitimde etkili yönetici davranışları. İzmir: Kanyılmaz Matbaası Yayınları.

3. Aydın, M. (2000). Eğitim yönetimi. (6. Baskı) Ankara: Hatipoğlu Yayınevi. ISBN: 9757527386

4. Aydın, M. (2014). Eğitim yönetimi: kavramlar, kuramlar, süreçler, ilişkiler. (10. Baskı). Ankara: Gazi Yayınları, ISBN 9786053441540

5. Asar, Ç. (2014). İlkokul yöneticilerinin yeterliliklerine ve iletişim becerilerine ilişkin yönetici ve öğretmenlerin görüşlerinin incelenmesi [Inspecting the Opinions of Primary School Administrators and Teachers in Relation to the Qualifications and Communication Skills of Administrators]. Yayımlanmamış Yüksek Lisans Tezi. Adana: Çukurova Üniversitesi Sosyal Bilimler Enstitüsü.

6. Ağaoğlu, E., Altınkurt, Y., Yılmaz, K. ve Karaköse, T. (2012). Okul yöneticilerinin yeterliklerine ilişkin okul yöneticilerinin ve öğretmenlerin görüşleri (Kütahya ili). Eğitim ve Bilim Dergisi, 37 (164), 159-175. Available at: http://egitimvebilim.ted.org.tr/index.php/EB/article/v iew/715/371

7. Baltacı, A. (2017). Okul müdürlerinin iş doyumları ile öz yeterlilik algıları arasında ilişki, Ihlara Eğitim Araştırmaları Dergisi, 2 (1), 49-76. Available at: http://ihead.aksaray.edu.tr/tr/pub/issue/30186/325869 
8. Balyer, A. (2016). School principal's administrative competency: Teachers views. YILDIZ Journal of Educational Research, 1 (1), 16-36. https://doi.org/10.51280/yjer.2016.002

9. Barut, E. (2007). İlköğretim okullarına sınavla atanan yöneticilerle, sınavsız atanan yöneticilerin yönetim süreçlerine ilişkin yeterliklerinin değerlendirilmesi: Sakarya İli örneği [Evaluations of Administraters, Who Were Appointed by an Exam and Without an Exam, Competences Relation with the Administrating Processes]. Yayımlanmamış Yüksek Lisans Tezi. Sakarya: Sakarya Üniversitesi Sosyal, Bilimler Enstitüsü.

10. Başar, H. (2000). Eğitim denetçisi. (5. Bask1). Ankara: Pegem Yayınları. ISBN: 9756802294

11. Başaran, İ.E. (2006). Türk eğitim sistemi ve okul yönetimi. Ankara: Ekinoks Yayınları. ISBN: 9789944495028

12. Bursalığlu, Z. (1981). Eğitim yöneticisinin yeterlikleri: ilk öğretmen okulu müdürlerinin yeterliklerine ilişkin bir araştırma. (2. Baskı). Ankara: Ankara Üniversitesi Eğitim Fakültesi Yayınları.

13. Büyüköztürk, Ş. (2010). Sosyal bilimler için veri analizi el kitabı. (12. Baskı), Ankara: Pegem Akademi. ISBN: 975680274X

14. Can, E.T. (2014). Eğitim kurumları yönetici atamayer değiştirme usul ve kriterleri ile ilgili yönetici görüşleri [Manager Opinions on Management Appointments - Replacement Methods and Criteria on Education]. Yayımlanmamış Yüksek Lisans Tezi. Uşak: Uşak Üniversitesi, Sosyal Bilimler Enstitüsü.

15. Çelik, V. (1990). Okul yöneticilerin eğitim yöneticisi yetiştirme politikasına ilişkin görüşleri [Opinions of School Administrators on Education Administrator Training Policy].Yayımlanmamıs Doktora Tezi. Elazığ: Fırat Üniversitesi, Sosyal Bilimler Enstitüsü.

16. Çepni, S. (2007). Araştırma ve proje çalışmalarına giriş. (3. Baskı). Trabzon: Celepler Matbaacılık Yayınları. ISBN: 9754170002

17. Çetin, N. (2008). Kuramsal liderlik çözümlemelerinin ışığında, okul müdürlüğ̈̈ ve eğitilebilir durumsal liderlik özellikleri. Pamukkale Üniversitesi Eğitim Fakültesi Dergisi, 1 (23), 74-84. Available at: https://dergipark.org.tr/tr/download/articlefile/114697

18. Demir, K.N. (2009). Uluslararası Bakalorya diploma programına ilişkin yönetici, öğretmen, veli ve mezun görüşleri [The Points of the Principals, Teachers, Parents and Graduate International Baccalaureate Diploma Programme]. Yayımlanmamış Doktora Tezi.
Ankara: Ankara Üniversitesi, Eğitim Bilimleri Enstitüsü.

19. Eren, E. (2012). Örgütsel davranış ve yönetim psikolojisi. (13. Baskı). İstanbul: Beta Yayınları. ISBN: 9786053777779

20. Gök, R. (2017). Türkiye eğitim sisteminde meritokrasi ve liyakat esaslı yönetici yetiştirme, atama değerlendirme sistemi ile liyakatlı yönetici niteliklerinin incelenmesi: bir karma yöntem araştırması [The Examination of Meritocracy and Merit Based Administrator Training, Appointment, Evaluation System and the Qualifications of Capable Administrator in the Turkish Education System: A Mixed Typed Study]. Yayımlanmamıs Doktora Tezi. Antalya: Akdeniz Üniversitesi, Eğitim Bilimleri Enstitüsü.

21. Gökçe, F. (2008). Değişimin kavramsal modelleri ve değişim sürecinde eğitim yöneticilerinin yeterlikleri. Eğitim Dergisi, 172, 237-252. Available at: https://dergipark.org.tr/tr/pub/maeuefd/article/48070 $\underline{0}$

22. Gülşen, C. ve Gökyer, N. (2012). Türk eğitim sistemi ve okul yönetimi. (2. Baskı), Ankara: Anı Yayınları. ISBN: 6054434373

23. Huck, S.W. (2012). Reading statistics and research. (6th ed.). Boston Massachusetts: Pearson Education, Inc. ISBN: 9780132178631

24. Kaptan, S. (1998). Bilimsel araştırma teknikleri ve istatistik yöntemleri. (11. Baskı). Ankara: Tekışı Web Ofset Tesisleri Yayınları.

25. Karasar, N. (2008). Bilimsel araştırma yöntemi. (18. Baskı). Ankara: Nobel Yayınları.

26. Kaya, Y.K. (1993). Eğitim yönetimi: kuram ve Türkiye'deki uygulama. (5. Baskı). Ankara: Bilim Yayınları.

27. Kayıkçı, K. (2001). Yönetici yetiştirme sorunu. Eğitim Dergisi, 150, 28-32. Available at: https://dhgm.meb.gov.tr/yayimlar/dergiler/Milli_Egit im_Dergisi/150/kayikci.htm

28. Kırhan, T. (2009). Bir okul müdürünün yönetim ve liderlik anlayışının değerlendirilmesi (örnek olay incelemesi) [Assessment of a Principal's Management and Leadership Mentality: A Case Study]. Yayımlanmamış Yüksek Lisans Tezi. İstanbul: Yeditepe Üniversitesi, Sosyal Bilimler Enstitüsü.

29. Kombıçak, M. (2008). İlköğretim okulu müdürlerinin yeterliliklerinin incelenmesi [ A Research for the Professional Sufficiency of Primary School managers]. Yayımlanmamış Yüksek Lisans Tezi. 
İstanbul: Yeditepe Üniversitesi, Sosyal Bilimler Enstitüsü.

30. Lunenburg, C.F. (2010). The principal and the school: what do principals do? Natıonal Forum of Educatıonal Adminıstratıon and Supervision Journal, 27 (4), 1-13.

Available at:

http://www.nationalforum.com/Electronic\%20Journa $1 \% 20$ Volumes/Lunenburg, $\% 20$ Fred $\% 20$ C. $\% 20$ The $\%$ 20Principal $\% 20$ and $\% 20$ the $\% 20$ School $\% 20$ \%20What\%20Do\%20Principals\%20Do\%20NFEASJ \%20V27,\%20N4,\%202010.pdf

31. MASHT, (2020), Statistikat e arsimit në Kosovë, Prishtinë. Available at: https://masht.rks.gov.net/uploads/2020/07/statistikate-arsimit-2019-2020_1.pdf (Accessed at: 24.07.2020).

32. Munis, V. (2006). İlköğretim okullarında görev yapan müdürlerin kişisel ve yönetsel profilleri. Yayımlanmamış Yüksek Lisans Tezi [The Personal and Administrative Profiles of the School Principals Working at Primary Schools (A Case Study in Gaziantep)]. Gaziantep: Gaziantep Üniversitesi, Eğitim Bilimleri Enstitüsü.

33. Pallant, J. (2007). SPSS survival manual-a step by step guide to data analysis using SPSS for windows (3rd Ed.). Maidenhead: Open University Press. ISBN10: 0335223664

34. Patton, M.Q. (2005). Qualitative research. New York: John Wiley and Sons. https://doi.org/10.1002/0470013192.bsa514

35. Özdere, Z. (2015). Öğretmen algılarına göre okul müdürlerinin yeterlilik düzeyleri ile örgütsel güven düzeyi arasındaki ilişkinin incelenmesi (Beykoz ilçesi örneği) [According to Teacher Perceptions, the Assesment of the Relationship Between the Organizational Trust and the Proficiency Level of School Managers]. Yayımlanmamış Yüksek Lisans Tezi. İstanbul: Yeditepe Üniversitesi, Sosyal Bilimler Enstitüsü.

36. Özdemir, S. (1988). Eğitim yöneticisinin değerlendirilmesi [Evaluation of Educational Administrators]. Yayımlanmamış Doktora Tezi. Konya: Selçuk Üniversitesi, Sosyal Bilimler Enstitüsü.

37. Uslu, B. (2013). Eğitim yönetimindeki akademisyenlerin okul yöneticilerinin yeterliklerine ilişkin görüşleri. Marmara Üniversitesi Atatürk Eğitim Fakültesi Eğitim Bilimleri Dergisi, 37, 172188 . Available at: https://dergipark.org.tr/tr/download/article-file/2159
38. Şişman, M. (2012). Türk eğitim sistemi ve okul yönetimi. (6. Baskı). Ankara: Pegem Yayınları. ISBN: 9786051704807

39. Şişman, M. (2013). Eğitimde mükemmellik arayışıetkili okullar. (3. Baskı). Ankara: Pegem Yayınları. ISBN: 9789756802946

40. Töremen, F. ve Kolay, Y. (2003). İlköğretim okulu yöneticilerinin sahip olması gereken yeterlikler. Eğitim Dergisi, 160, 341-350. Available at: https://dergipark.org.tr/tr/download/article$\underline{\text { file/108271 }}$

41. Tuzcuoğlu, N. (2009). Yöneticiliğin psikolojik özellikleri ve yıldırma. A. Oktay (Ed.). Türk eğitim sistemi ve okul yönetimi içinde (s. 373-396). İstanbul: Kriter Yayınları. ISBN: 9786055863227

42. Tümkaya, S. ve Asar, Ç. (2017). İlkokul yöneticilerinin yeterliklerine ilişkin görüşlerinin incelenmesi. Çukurova Üniversitesi Sosyal Bilimler Enstitüsü Dergisi, 26 (1), 242-253. Available at: https://dergipark.org.tr/tr/download/articlefile/361983

43. Yalçın, C. (2019). Okul yöneticilerinin yeterliliklerine ilişkin okul yöneticileri ve öğretmenlerin görüşleri (Eskişehir ili) [ Opinions of School Administrators and Theachers About Proficiency of School Administrators (In Eskişehir)]. Yayımlanmamış Doktora Tezi. Eskişehir: Eskişehir Osmangazi Üniversitesi, Eğitim Bilimleri Enstitüsü.

44. Yıldırım, A. ve Şimşek, H. (2016) Sosyal bilimlerde nitel araştırma yöntemleri. (10. Baskı) Ankara: Seçkin Yayıncıl1k. ISBN: 9789750239991 